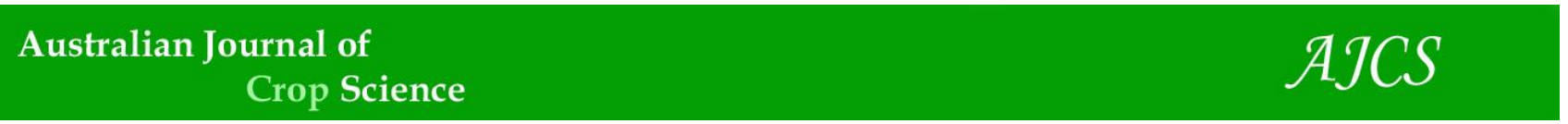

AJCS 14(12):1999-2009 (2020)

ISSN:1835-2707

doi: 10.21475/ajcs.20.14.12.2883

\title{
Inheritance of resistance against Peronospora destructor in onion cv. 'Regia'
}

\author{
Mariana Arias ${ }^{1 *}$, Natalia Curbelo ${ }^{1}$, Pablo González Rabelino ${ }^{2}$, Esteban Vicente ${ }^{3}$, Gustavo Giménez ${ }^{4}$, \\ Guillermo A. Galván ${ }^{1}$
}

${ }^{1}$ Departamento de Producción Vegetal, Centro Regional Sur (CRS), Facultad de Agronomía. Universidad de la República, Uruguay

${ }^{2}$ Departamento de Protección Vegetal, Facultad de Agronomía. Universidad de la República, Uruguay

${ }^{3}$ Instituto Nacional de Investigación Agropecuaria (INIA), Programa Nacional de Horticultura. Salto Grande Exp. St., Uruguay

${ }^{4}$ Instituto Nacional de Investigación Agropecuaria (INIA), Programa Nacional de Horticultura. Wilson Ferreira

Aldunate, Las Brujas Exp. St, Uruguay

*Corresponding author: mariana.arias@fagro.edu.uy

\begin{abstract}
Onion downy mildew (DM) caused by Peronospora destructor is a very destructive leaf disease. Genetic resistance is an economic and environmentally friendly way of disease control. In this research, the segregation of DM resistance was analysed in six offspring from crosses between national cultivars and the cv. 'Regia', a partial resistance source. $F_{1}$ plants were self-fertilised, and $F_{1} S_{1}$ derived progenies were evaluated. The segregations in DM severity were skewed towards susceptibility, with transgressive segregation in five of six progenies. The recessive inheritance could be associated with loss of susceptibility mechanisms. In another experiment, the response of advanced $F_{1} S_{2}$ lines 'Regia' $x$ 'Pantanoso del Sauce' were evaluated two times (August and November 2017) in DM disease severity, DM histological quantitative differences, and agronomic traits. $F_{1} S_{2}$ lines, which have had an earlier selection process, presented an intermediate DM severity between the parents. Disease severity was positively correlated with histological differences in the proportion of infected stomata. 'Regia' presented the lowest DM severity and the highest percentage of healthy stomata. Most resistant $\mathrm{F}_{1} \mathrm{~S}_{2}$ lines did not differ from control cultivars in bulb yield, bulb quality traits and postharvest behaviour, and could be the basis to develop a DM resistant cultivar in comparison to currently grown cultivars.
\end{abstract}

Keywords: Oomycete, partial resistance, recessive resistance, transgressive segregation.

Abbreviations: Casera: onion cv. 'INIA Casera'; 'Pantanoso': 'Pantanoso del Sauce CRS'; 'Dulce': 'INIA Fagro Dulce'.

Introduction

Downy mildew caused by the oomycete Peronospora destructor Berk. Casp. is one of the main leaf diseases of onion (Allium cepa L.) in temperate climates (Schwartz and Mohan, 2008). Under prevailing environmental conditions, disease development is devastating and yield losses can be above $50 \%$ either for bulb or seed production (González et al., 2011). Typical symptoms are oval areas on leaves or floral stalks, up to $10-15 \mathrm{~cm}$ in length, light green to chlorotic with oily aspect, on which later the sporulation can be observed as a grey-purplish plush (Schwartz and Mohan, 2008; González et al., 2011).

Chemical control is available and effective (Araujo et al., $2020 \mathrm{~b}$ ), though has negative consequences and risks on the environment, labours and consumers' health, and crop profitability. Forecast systems have been implemented based on environmental conditions, aiming to spray, when only required (Lorbeer et al., 2002; Araújo et al., 2020a; Ullah et al., 2020). However, crop management under forecast systems relies on several chemical interventions under conducive weather conditions (Maeso et al., 2000; Scholten et al., 2007).
Host resistance is an economically and environmentally friendly disease control. Therefore, it is an extended goal in crop breeding programmes worldwide (Niks et al., 2011). Some studies have reported resistance against $P$. destructor in red onion lines (Jones et al., 1939; Warid and Tims, 1952). Some recent studies have described highly resistant onion varieties (Alves et al., 2018; Ullah et al., 2020). However, no complete resistance is available within the genetic basis of the species (Kofoet and Zingernagel, 1989). The Pd gene from Allium roylei was introgressed, and currently resistant cultivars are available (Scholten et al., 2007).

Basal resistance mechanisms and the recognition of pathogen associated with molecular markers can determine partial levels of resistance. These quantitative differences are expressed as epidemiological parameters leading to a slowdown of disease development. Such differences can be exploited in plant breeding, reducing the negative effects on crop yield, and contributing to an integrated crop management (Niks et al., 2011). The genetic basis of partial resistance is usually polygenic and has shown to be durable (Niks et al., 2011). 
Peronospora destructor is a difficult pathogen to selection for resistance (Galván et al., 2016a). It cannot be propagated and; therefore, sporulation and subsequent inoculum production is not easy, because is dependent of lesions on adult plants (Schwartz and Mohan, 2008; Maeso et al., 2000). Consequently, there is a large dependency of disease occurrence under natural conditions to select for resistance. From 2008, we screened for sources of resistance (Colnago et al., 2012) at Centro Regional Sur (CRS) of the Universidad de la República, Uruguay. We made crosses between 'Regia' and 'Pantanoso' in order to combine the resistance against downy mildew of the former with favourable agronomic traits from the latter (Galván et al., 2016a). The partial resistance from 'Naqué' was combined in crosses with 'Casera', and later on combined in a cross 'Regia $x$ (Naqué $x$ Casera)' at the INIA research institute in Salto Grande, North Uruguay (Galván et al. 2016b). As a preliminary hypothesis, the resistance from 'Regia' has been proposed as determined by various genes with additive and eventually recessive effects. The downy mildew spots collected from field trials were assessed through histological observations. The proportion of infected stomata was positively correlated with disease severity (Galván et al., 2016a, b). In addition, the analysis of initial steps of the infection process after experimental inoculation suggest that a complementary mechanism of resistance in 'Regia' could be the lack of recognition of the plant as a potential host before the establishment of the infection (Galván et al., 2016a).

The knowledge on the inheritance of resistance from 'Regia' would contribute to an efficient use in plant breeding. This research aimed to study the segregation of resistance to Peronospora destructor and agronomic traits using 'Regia' as resistance source and to evaluate advanced breeding lines previously selected for downy mildew resistance.

\section{Results}

\section{Segregation of resistance from 'Regia'}

Peronospora destructor severity was evaluated through a progeny test in six segregating families from crosses between 'Regia' as resistance source and susceptible cultivars (Figure 1). The Kolmogorov-Smirnov test ( $R$ platform) proved the normal distribution of the means of the lines in four families, but not for the families 15601 and 14611.

The families 'Regia' x 'Santina' (15605), 'Regia' x 'Casera' (14603) and 'Regia' x 'Dulce' (14606) showed significant differences between lines in disease severity (Table 1), whereas did not significantly differ among them within the families 'Regia' x 'Naqué' (15601), 'Regia' x 'Pantanoso' (14609) and 'Dulce' $x$ 'Regia' (14611). In the six families, some lines did not significantly differ from 'Regia', even when 'Regia' presented the lowest average severity in all cases.

Figure 2 presents frequency histograms of disease severity for each family and the controls. Four of the six progenies had skewed segregations towards the susceptible parent. Even more, the progenies 'Regia' $x$ 'Naqué' and 'Regia' $x$ 'Casera' presented skewed and transgressive segregation towards susceptibility, with some lines more susceptible than the susceptible parent. In the progeny 'Regia' $x$ 'Santina' all lines were intermediate between the parents with skewed segregation towards 'Santina', the susceptible parent, whereas 'Regia' x 'Pantanoso' (14609) had a
Gaussian distribution with a modal value between the parents.

After reciprocal crosses 'Regia' x 'Dulce' (14606) and 'Dulce' x 'Regia' (14611), all lines were intermediate between the parents (Figure 2). When 'Regia' acted as female (14606), the segregation was intermediate between the parents and skewed towards susceptibility, in a similar way than other described families. However, when 'Regia' acted as pollen donor (14611) the progeny was intermediate and skewed towards resistance.

'Pantanoso' presented the largest average bulb weight, neck thinness, and better postharvest conservation (Table 2). The family 'Regia' x 'Santina' showed high average bulb weight, better than other control cultivars, indicating the expression of hybrid vigour. Five of the six progenies showed intermediate values between the parents for neck thinness and postharvest conservation, with values outperforming those of 'Regia'.

The segregation of bulb colour within families was broader than that observed within improved cultivars (Figure 3). The larger proportion of individuals was brown to light brown in all progenies. Reddish colours appeared to be associated with brownish colours. The segregation of bulb shape was larger within segregating families than the control cultivars, as expected (Figure 4). Most individuals were round shape, elongated-round, and high-top shaped. Segregating populations presented larger proportion of elongated and elongated-round bulbs than parental cultivars.

\section{Evaluation of advances breeding lines $P \times R F_{1} S_{2}$}

In a second experiment, eleven advanced breeding lines $F_{1} S_{2}$ 'Regia' x 'Pantanoso' (PxR) and two regenerated open populations from breeding lines were evaluated for downy mildew resistance, in August and November 2017. In both evaluation times, disease severity significantly differed among plant material (Kruskall-Wallis, $p<0.05$ ), but not between evaluation times (for $p$-value $=0.05$, nor for 0.10 ), neither for the interaction between evaluation time and genetic materials.

Means were analysed within evaluation times (Table 3). In August, 'Regia' presented the lowest severity, whereas the cultivars 'Pantanoso', 'Santina' and 'Casera' showed higher severity values. 'Naqué' had an intermediate behaviour, moderately susceptible. Advanced $F_{1} S_{2}$ breeding lines and derived populations showed intermediate responses between the parents. As expected, the 'PxR elite' population composed by the inter-pollination of the eleven selected lines was more resistant than 'PxR general', composed by non-selected lines in 2015. The lines 22E, 22D, 22B and 10A presented the lower mean severity values after 'Regia' (Table 3). The population 'PxR general' was significantly better than susceptible cultivars but more diseased than the best lines and did not represent a substantial progress in resistance.

In November, 'Regia' was the most resistant and significantly different plant material (Table 3). The lines 22E, 22D, 22B were again following 'Regia' in resistance. For most lines, severity was higher in November than August. However, 22D, 22B and 'Naqué' presented lower disease severity in the second evaluation.

Average bulb weight did not differ between breeding lines nor between control cultivars ( $p$-value $=0.176$, data not shown). Plant material did differ in postharvest conservation ( $p$-value < 0.001) (Table 3). The cultivars 'Pantanoso' and 
'Naqué' presented a postharvest conservation above $90 \%$, as well as 'PxR general' and the lines 22B, 22D, 22F, 5B and $10 \mathrm{E}$. The line $22 \mathrm{E}$ showed the lowest conservation (61.8\%), followed by 'Santina' and the lines 10B and 10A. The line 22E presented the highest bolting percentage, followed by 'Santina' and the lines $10 \mathrm{~A}$ and $10 \mathrm{~B}$.

\section{Histological observations of diseased leaf tissue}

The histological composition of infected leaf tissue in samples collected from field trials were assessed simultaneously with disease severity (August and November), in three categories (Figure 4). The proportion of healthy stomata in breeding lines and regenerated populations was intermediate between the parents 'Regia' and 'Pantanoso' (Figure 5), a result comparable to the evaluation of severity in the field (Table 3 ), with significant differences between lines ( $p$-value $<0.0001$ ).

As a general trend, the proportion of healthy stomata were higher in August than November, with a higher proportion of sporulating stomata and a lower proportion of sub-stomatal infections in comparison to November (Table 5). In August, 'Regia' showed the largest proportion of healthy stomata, statistically different than other plant material. 'Pantanoso' showed $40.4 \%$ of healthy stomata in August, $58.9 \%$ sporulating and $2.8 \%$ with sub-stomatic infections. Healthy stomata for 'Pantanoso' rose in November (45\%), substomata infections were increased and sporulating stomata decreased (Figure 5).

Breeding lines 10A, 22B, 10E, 22F and 22D presented the higher proportion of healthy stomata after 'Regia'. The 'PxR elite' population had higher proportion of healthy stomata than 'PxR general', a statistically significant difference. The cultivar 'Naqué' was intermediate, and the samples in August presented immature sporangia, whereas other control cultivars showed mature sporangia and even some already developing hypha capable to initiate a secondary infection. 'Casera' had the lowest proportion of healthy stomata, significantly different than other susceptible cultivars (Table 5).

For the whole experiment, the proportion of sporulating stomata in August was significantly higher than that in November ( $p$-value < 0.0001) (Table 5). In August, 'Regia' presented the lowest proportion of sporulating stomata, followed by the lines $22 \mathrm{~B}$ and 22D, significantly different than other lines and cultivars. The cultivars with a higher proportion of sporulation through stomata were 'Casera', 'Pantanoso' and 'Santina'. In November, line 22E and 'PxR general' presented significantly lowest proportion of sporulating stomata, whereas 'Pantanoso', 'Naqué' and 10D showed the largest proportion.

The correlation between disease severity and the proportion of healthy stomata for both evaluation times was negative (Pearson $r=-0.73 ;$ P-value $=0.0008$ ). The correlation between disease severity and the proportion of sporulating stomata was positive $(r=0.57, p$-value $=0.01)$.

In the multivariate analysis (PCA), the principal component 1 and 2 explained $34.0 \%$ and $23.2 \%$ of the total variability, respectively (Figure 6). Vectors for disease severity and the proportion of healthy stomata explained the main share of variation for principal component 1 . Vectors for postharvest conservation, bolting and bulb weight explained most variation for principal component 2. Variables for disease severity in August and November were opposite to the proportion of healthy stomata, evidencing that these variables are negatively associated. Plant materials more associated to disease severity were 'Pantanoso' and 'Santina', followed by the lines $10 \mathrm{D}$ and $5 \mathrm{~A}$. In contrast to disease severity in 'Regia', the most distal position followed by the lines 22B, 22D, 22F, 22E and 10A. Average bulb weight and bolting appeared as independent from downy mildew resistance, and therefore can be selected simultaneously. Postharvest conservation was opposite of bolting, indicating that plant materials with higher premature flowering lead to a lower postharvest behaviour (Figure 6).

\section{Discussion}

The high level of partial resistance in 'Regia' has been consistent with previous reports (Galván et al., 2016a). Analysis of 'Regia' as a resistance source has shown quantitative and variable segregation in the progenies. This gives clues towards the presence of diverse mechanisms of partial resistance. Regarding the diverse results obtained, genetic variation among individuals within open pollinated varieties used for plant-to-plant crosses should be taken into account, including 'Regia' as a source of partial resistance.

The sizes of the segregating populations were small to test hypothesis on the genetic basis of the trait, although several populations with different genetic backgrounds were studied simultaneously, adding robustness to the analysis (McMullen et al., 2009). Four of the six studied progenies showed a segregation skewed towards susceptibility, a result coincident with previous works from our group (Galván et al., 2016a, Galván et al., 2016b). This result is also in line with Warid and Tims (1952), who selected for resistance in US. They reported recessive genes controlling the trait, with 2.8 to $24 \%$ of resistant plants in F2 families. In the cross 'Regia' $x$ 'Pantanoso' the segregation was intermediate between the parents. This was an expected response for a partial resistance with quantitative expression, in which many genes with cumulative quantitative effect were involved. In general, partial resistance is a trait with quantitative inheritance that was explained by the involvement of many minor genes. A continuous segregation is expected in biparental populations like those studied in this research (Niks et al., 2011).

The crosses between 'Regia' and the cultivars 'Naqué' 'Dulce', 'Santina' and 'Casera' presented skewed segregations towards susceptibility. 'Naqué' is moderately susceptible as observed in this research, with a specific response. It can be early colonized, with high incidence values early in the season, but not leading to high severity values in further evaluations (Galván et al. 2016a). However, some lines derived from the cross with 'Regia' were more susceptible than 'Naqué', with transgressive segregation. In this family, both parents may contribute to resistance. The chance that some individuals accumulated favourable alleles from both parents was possible, leading to a resistant transgressive segregation if alleles coming from each parent differ and accumulate in some individuals (Aghnoum and Niks, 2011). A segregation skewed towards susceptibility could be caused by accumulation of unfavourable alleles or epistatic combinations conferring susceptibility in some individuals.

Aghnoum and Niks (2011) studied partial resistance against powdery mildew and found that transgressive segregation is a common phenomenon in barley. A great diversity of genes with quantitative effect contribute to disease resistance. 
Table 1. Test for mean comparisons (Tukey) within the three segregating families with significant differences among breeding lines. For each family, control cultivars plots were included.

\begin{tabular}{|c|c|c|c|}
\hline \multirow[b]{2}{*}{ Identification } & \multicolumn{3}{|c|}{ Segregating families ${ }^{a}$} \\
\hline & $\begin{array}{c}15605 \\
\text { Regia } \times \text { Santina }\end{array}$ & $\begin{array}{c}14603 \\
\text { Regia } \times \text { Casera }\end{array}$ & $\begin{array}{c}14606 \\
\text { Regia x Dulce }\end{array}$ \\
\hline \multicolumn{4}{|c|}{ F1S1 breeding lines ${ }^{b}$} \\
\hline \multirow[t]{5}{*}{ Segregation } & $4(1.63-1.83)$ a & $3(2.50-3.12)$ a & $1(2.54) \mathrm{a}$ \\
\hline & $10(2.35-2.48) \mathrm{ab}$ & $4(3.20-3.24) \mathrm{ab}$ & $3(2.74-2.77) a b$ \\
\hline & $42(2.50-3.40) a b c$ & $11(3.26-4.00) a b c$ & $6(2.80-3.40) a b c$ \\
\hline & $10(3.46-3.53) b c$ & $2(4.18-4.20) b c$ & $2(3.37-3.48) b c$ \\
\hline & $7(3.69-3.90) \mathrm{c}$ & $2(4.25-4.53) \mathrm{c}$ & $2(3.52-3.64) c$ \\
\hline Total Nr of lines & 74 & 22 & 14 \\
\hline \multicolumn{4}{|l|}{$\overline{\text { Control Cultivars }}$} \\
\hline Regia & $1.10 \mathrm{a}$ & $1.10 \mathrm{a}$ & $0.75 \mathrm{a}$ \\
\hline Naqué & $2.35 \mathrm{ab}$ & $2.26 \mathrm{a}$ & $2.05 \mathrm{a}$ \\
\hline Pantanoso & $3.50 \mathrm{bc}$ & $3.30 \mathrm{abc}$ & $3.53 \mathrm{bc}$ \\
\hline Casera & $4.18 \mathrm{c}$ & $4.00 a b c$ & $4.00 \mathrm{c}$ \\
\hline
\end{tabular}

(berity.
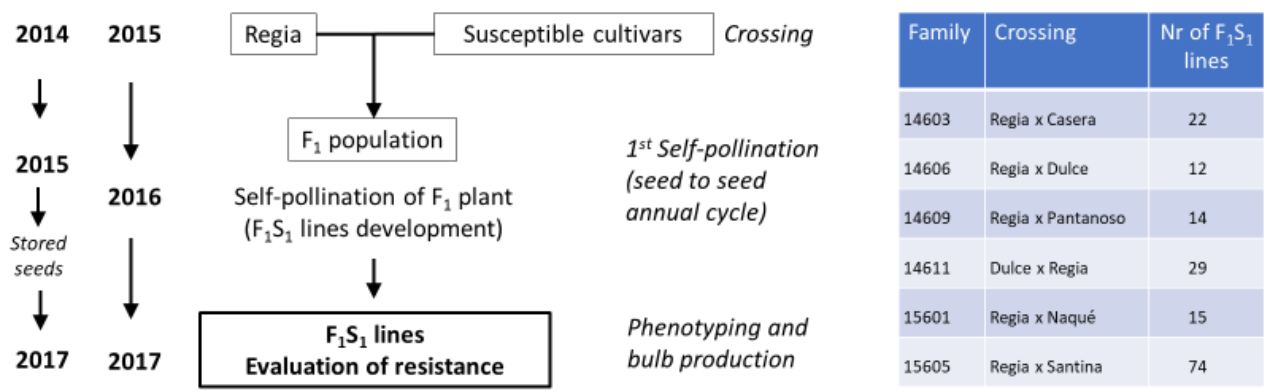

Fig 1. Breeding scheme to develop six onion segregating populations combining resistance against Peronospora destructor from 'Regia' with favourable agronomic traits in national cultivars.

Table 2. Segregating progenies and control cultivars. Number of lines per family and mean values for agronomic traits.

\begin{tabular}{|c|c|c|c|c|c|}
\hline Plant material & Crossings & Nr of lines & Average bulb weight $(\mathrm{g})^{\mathrm{c}}$ & Neck thinness ${ }^{a c}$ & Postharvest conservation $(\%)^{\mathrm{bc}}$ \\
\hline \multicolumn{6}{|c|}{ Segregating progenies } \\
\hline 14603 & Regia $\times$ Casera & 22 & $64.3 \mathrm{f}$ & $12.0 \mathrm{c}$ & $73.5 \mathrm{~b}$ \\
\hline 14606 & Regia x Dulce & 12 & $72.5 \mathrm{e}$ & $13.4 \mathrm{c}$ & $66.4 \mathrm{c}$ \\
\hline 14609 & Regia $\times$ Pantanoso & 14 & $62.8 \mathrm{f}$ & $12.9 \mathrm{c}$ & $68.8 \mathrm{c}$ \\
\hline 14611 & Dulce $x$ Regia & 29 & $80.9 \mathrm{~d}$ & $11.6 \mathrm{~cd}$ & $71.9 \mathrm{~b}$ \\
\hline 15601 & Regia $\times$ Naqué & 15 & $78.5 \mathrm{~d}$ & 9.6 de & $32.9 \mathrm{f}$ \\
\hline 15605 & Regia $\times$ Santina & 74 & $126.6 \mathrm{a}$ & $12.4 \mathrm{c}$ & $61.5 \mathrm{~d}$ \\
\hline \multicolumn{6}{|l|}{ Control cultivars } \\
\hline Pantanoso & - & - & $110.3 \mathrm{~b}$ & $20.1 \mathrm{a}$ & $84.9 \mathrm{a}$ \\
\hline Regia & - & - & $104.6 \mathrm{c}$ & $7.2 \mathrm{e}$ & $33.7 \mathrm{f}$ \\
\hline Casera & - & - & $63.3 \mathrm{f}$ & $9.4 \mathrm{e}$ & $40.2 \mathrm{e}$ \\
\hline Naqué & - & - & $65.1 \mathrm{f}$ & $16.1 \mathrm{c}$ & $69.3 \mathrm{c}$ \\
\hline
\end{tabular}

${ }^{\mathrm{a}}$ Neck thinness: ratio between the maximum bulb diameter and the neck diameter. ${ }^{b}$ Percentage of marketable bulbs five months after harvest (in May 2018). ${ }^{\mathrm{c}}$ Means followed by the same letter are not significantly different $(\mathrm{p} \leq 0.05)$. 

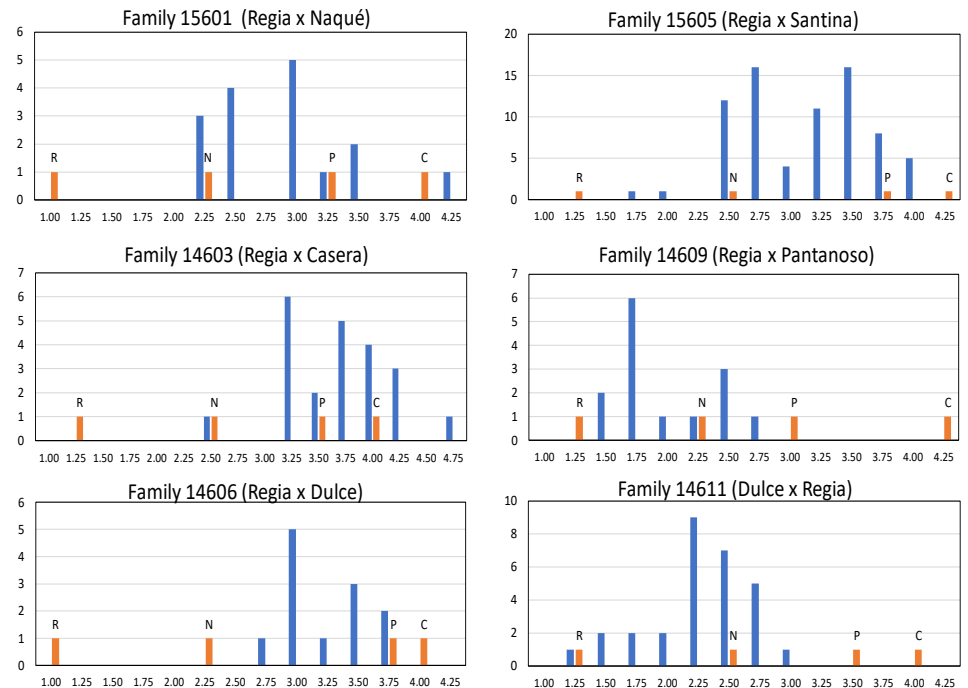

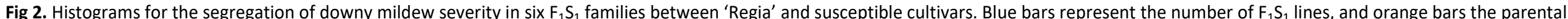
and control cultivars: 'Regia' (R). 'Naqué' (N). 'Pantanoso' (P) and 'Casera' (C).

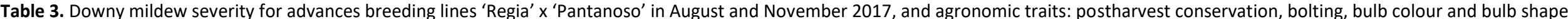

\begin{tabular}{|c|c|c|c|c|c|c|c|c|}
\hline \multirow{2}{*}{$\begin{array}{l}\text { Plant material } \\
\text { Regia }\end{array}$} & \multirow{2}{*}{$\begin{array}{l}\text { Disease severity }{ }^{\mathrm{D}} \\
\text { August } \\
0.81 \mathrm{a}\end{array}$} & \multirow{2}{*}{$\begin{array}{l}\text { November } \\
1.00 \mathrm{a}\end{array}$} & \multicolumn{2}{|c|}{ Postharvest conservation (\%) $^{\mathrm{a}}$} & \multicolumn{2}{|c|}{$\begin{array}{l}\text { Bolting } \\
(\%)^{\mathrm{a}}\end{array}$} & \multirow{2}{*}{$\begin{array}{l}\text { Bulb Colour } \\
\text { Brown light }\end{array}$} & \multirow{2}{*}{$\begin{array}{l}\text { Bulb shape } \\
\text { Round elongated }\end{array}$} \\
\hline & & & 89.0 & bcde & 4.0 & $a b c$ & & \\
\hline $22 \mathrm{E}$ & $1.61 \mathrm{~b}$ & $1.98 \mathrm{~d}$ & 61.8 & a & 37.5 & f & Brown reddish & Round elongated \\
\hline 22D & $1.86 \mathrm{bc}$ & $1.58 \mathrm{bc}$ & 91.8 & cde & 4.5 & $a b c$ & Brown light & High top \\
\hline $22 \mathrm{~B}$ & $1.95 \mathrm{~cd}$ & $1.45 \mathrm{~b}$ & 91.0 & bcde & 7.5 & abcd & Brown reddish & High top \\
\hline $10 \mathrm{~A}$ & $2.00 \mathrm{cde}$ & $3.26 \mathrm{jk}$ & 83.3 & bcd & 15.3 & bcde & Brown & Round flat \\
\hline PxR elite & $2.05 \mathrm{cde}$ & $2.28 \mathrm{ef}$ & 87.8 & bcde & 8.3 & abcd & Brown & Round \\
\hline $22 \mathrm{~F}$ & $2.11 \mathrm{cde}$ & $2.11 \mathrm{de}$ & 92.0 & cde & 6.5 & abcd & Brown reddish & Round \\
\hline Naqué & 2.24 def & $1.83 \mathrm{~cd}$ & 96.8 & e & 0.0 & a & Red & Round elongated \\
\hline $9 B$ & $2.26 \mathrm{ef}$ & $2.44 \mathrm{fg}$ & 86.0 & bcde & 8.0 & abcd & Brown & High top \\
\hline 10B & $2.43 \mathrm{fg}$ & $2.80 \mathrm{hi}$ & 80.3 & bc & 18.0 & de & Brown light & Round elongated \\
\hline $10 \mathrm{D}$ & $2.44 \mathrm{fg}$ & $2.51 \mathrm{fgh}$ & 85.5 & bcde & 12.0 & abcde & Brown light & High top \\
\hline $5 \mathrm{~A}$ & $2.45 \mathrm{fg}$ & $2.44 \mathrm{fg}$ & 88.8 & bcde & 6.5 & $a b c d$ & Brown reddish & High top \\
\hline $5 B$ & $2.44 \mathrm{fg}$ & $2.68 \mathrm{ghi}$ & 92.8 & cde & 4.5 & $a b c$ & Brown & High top \\
\hline $10 \mathrm{E}$ & $2.75 \mathrm{gh}$ & $3.18 \mathrm{j}$ & 94.8 & de & 4.5 & abcd & Brown dark & High top \\
\hline PxR general & $2.84 \mathrm{~h}$ & $2.86 \mathrm{i}$ & 95.5 & de & 1.5 & $a b$ & Brown & Round \\
\hline Pantanoso & $3.81 \mathrm{i}$ & $4.15 \mathrm{~m}$ & 92.0 & cde & 3.0 & $a b c$ & Brown dark & Round \\
\hline Santina & $3.90 \mathrm{i}$ & $3.56 \mathrm{kl}$ & 78.3 & b & 20.5 & e & Brown & Round elongated \\
\hline
\end{tabular}



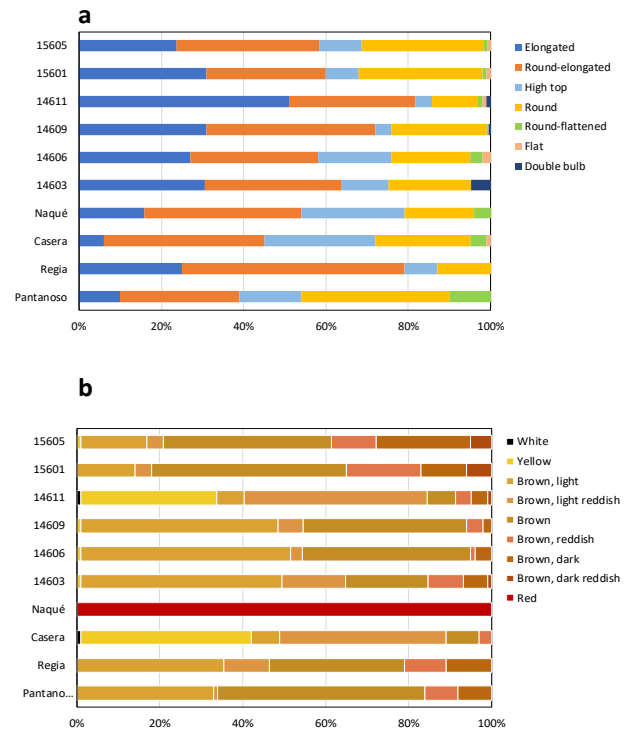

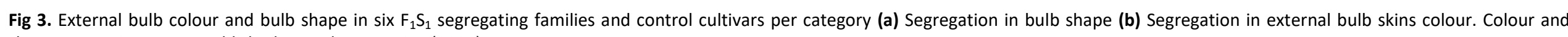
shape categories were established according to IPGRI (2001).

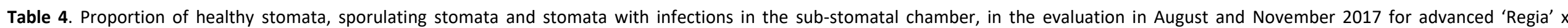
'Pantanoso' breeding lines and control cultivars.

\begin{tabular}{|c|c|c|c|c|c|c|c|c|c|c|}
\hline \multirow{3}{*}{$\begin{array}{l}\text { Plant material } \\
\text { Regia }\end{array}$} & \multicolumn{2}{|c|}{ Healthy stomata } & \multicolumn{4}{|c|}{ Sporulating stomata } & \multicolumn{4}{|c|}{ Infected stomata } \\
\hline & \multirow{2}{*}{$\begin{array}{l}\text { August (\%) } \\
95.9 \mathrm{a}\end{array}$} & November (\%) & \multicolumn{2}{|c|}{ August (\%) } & \multicolumn{2}{|c|}{ November (\%) } & \multicolumn{2}{|c|}{ August (\%) } & \multicolumn{2}{|c|}{ November (\%) } \\
\hline & & - & 1.6 & $\mathrm{a}$ & - & & 2.5 & cde & - & \\
\hline $10 \mathrm{~A}$ & $87.3 \mathrm{~b}$ & $74.8 \mathrm{c}$ & 12.7 & de & 20.0 & de & 0 & a & 5.3 & c \\
\hline $22 \mathrm{~B}$ & $85.9 \mathrm{~b}$ & $66.8 \mathrm{~d}$ & 3.4 & b & 8.0 & b & 10.9 & $f$ & 25.2 & f \\
\hline 10E & $85.4 \mathrm{bc}$ & 51.3 ef & 14.6 & e & 23.8 & f & 0 & a & 24.9 & $f$ \\
\hline $22 \mathrm{~F}$ & $83.3 \mathrm{bc}$ & $73.0 \mathrm{c}$ & 15.8 & ef & 13.8 & c & 0.9 & $a b c$ & 13.2 & $d$ \\
\hline $22 \mathrm{D}$ & $82.4 \mathrm{bc}$ & 88.4 a & 6.7 & c & 6.9 & b & 10.7 & f & 4.7 & c \\
\hline PXR general & $79.7 \mathrm{~cd}$ & 53.3 ef & 20.0 & $\mathrm{fg}$ & 4.5 & a & 0.3 & $a b$ & 42.3 & $\mathrm{~h}$ \\
\hline $5 B$ & $75.9 \mathrm{~d}$ & $64.1 \mathrm{~d}$ & 9.8 & d & 20.1 & ef & 14.3 & f & 10.8 & d \\
\hline $22 \mathrm{E}$ & $75.6 \mathrm{de}$ & $83.0 \mathrm{~b}$ & 23.5 & $\mathrm{~g}$ & 2.1 & a & 0.9 & $a b c d$ & 13.9 & $d$ \\
\hline $9 B$ & 70.1 ef & $62.9 \mathrm{~d}$ & 9.7 & d & 8.7 & b & 20.2 & $\mathrm{~g}$ & 28.4 & ig \\
\hline PXR Elite & $67.8 \mathrm{fg}$ & 79.9 b & 32.2 & $\mathrm{~h}$ & 19.9 & $d$ & 0 & a & 2.3 & b \\
\hline $10 B$ & $64.6 \mathrm{gh}$ & $66.6 \mathrm{~d}$ & 35.0 & $\mathrm{~h}$ & 7.0 & b & 0.3 & $a b$ & 24.4 & $\mathrm{f}$ \\
\hline Naqué & $62.4 \mathrm{~h}$ & $32.4 \mathrm{~h}$ & 36.4 & $\mathrm{~h}$ & 64.9 & i & 1.2 & $a b c d$ & 2.7 & $\mathrm{~b}$ \\
\hline $5 \mathrm{~A}$ & $53.8 \mathrm{i}$ & 54.3 ef & 44.4 & $\mathrm{i}$ & 13.6 & c & 1.85 & bcde & 32.1 & $\mathrm{~g}$ \\
\hline $10 \mathrm{D}$ & $49.4 \mathrm{i}$ & $52.6 \mathrm{f}$ & 50.4 & ij & 47.4 & $\mathrm{~h}$ & 0 & a & 0 & a \\
\hline Pantanoso & $40.4 j$ & $45.0 \mathrm{~g}$ & 56.9 & $\mathrm{jk}$ & 37.1 & $\mathrm{~g}$ & 2.7 & de & 17.9 & e \\
\hline Santina & $39.1 \mathrm{j}$ & $55.4 \mathrm{e}$ & 55.9 & $\mathrm{jk}$ & 16.3 & $c d$ & 5.0 & e & 28.4 & $\mathrm{fg}$ \\
\hline Casera & $23.5 \mathrm{k}$ & - & 63.2 & $\mathrm{k}$ & - & & 13.3 & f & & \\
\hline
\end{tabular}




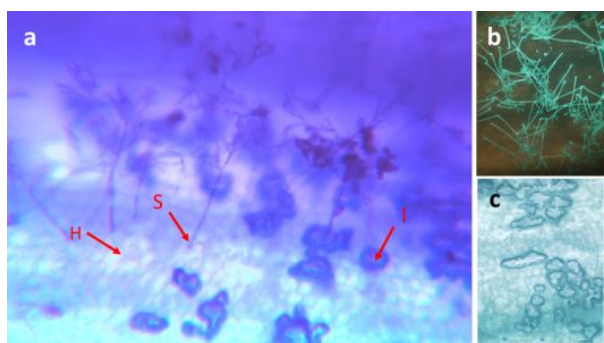

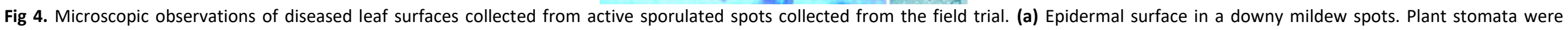

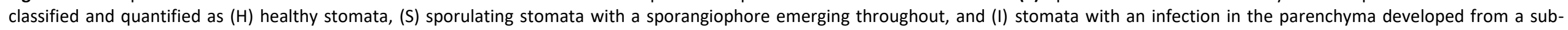

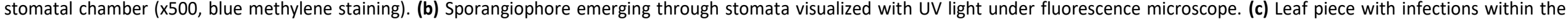
parenchyma. In transversal cuttings using a microtome (not shown), it was concluded that under-stomatal infections were old lesions, with dark borders caused by the collapse of death cells.

\begin{tabular}{lllllll}
\multicolumn{4}{l}{ Table 5. Ordinal scale for evaluation of Peronospora destructor severity expressed as a percentage of leaf area affected. } \\
\hline Classes & 0 & 1 & 2 & 3 & 4 & 5 \\
\hline Severity & 0 & $0<x \leq 5$ & $5<x \leq 15$ & $15<x \leq 30$ & $30<x \leq 50$ & $x>50$ \\
\hline
\end{tabular}
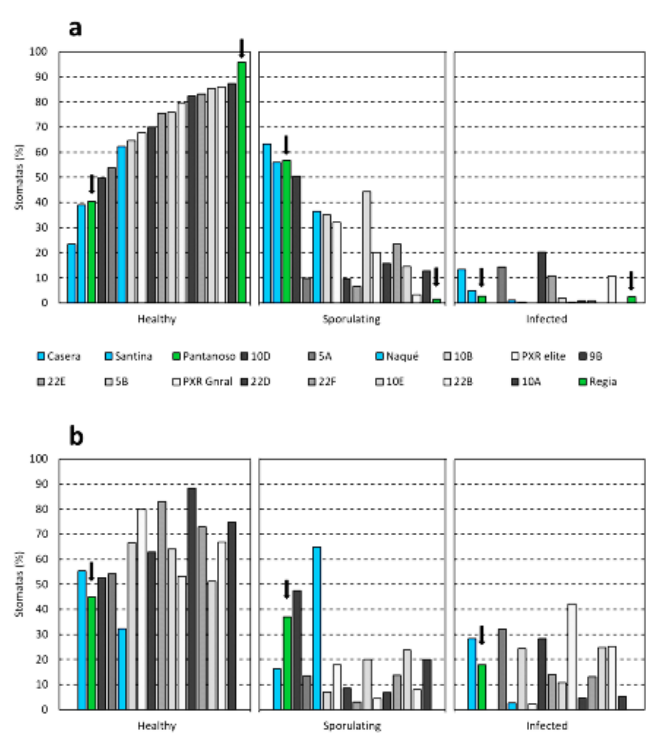

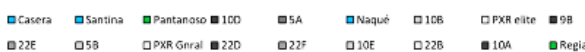

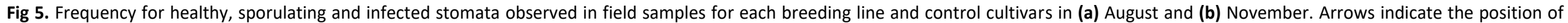
resistant ('Regia') and susceptible ('Pantanoso') parents (green columns). The early cultivars 'Regia' and 'Casera' were not evaluated in November because of the foliage senescence. 


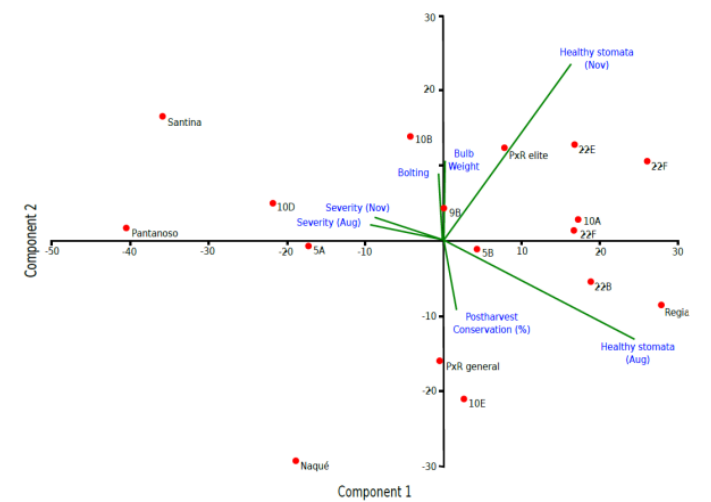

Fig 6. Principal components analysis for the $F_{1} S_{2}$ advances breeding lines from a cross 'Regia' $\mathrm{x}$ 'Pantanoso' and the onion control cultivars, in resistance to Peronospora destructor and agronomic variables.

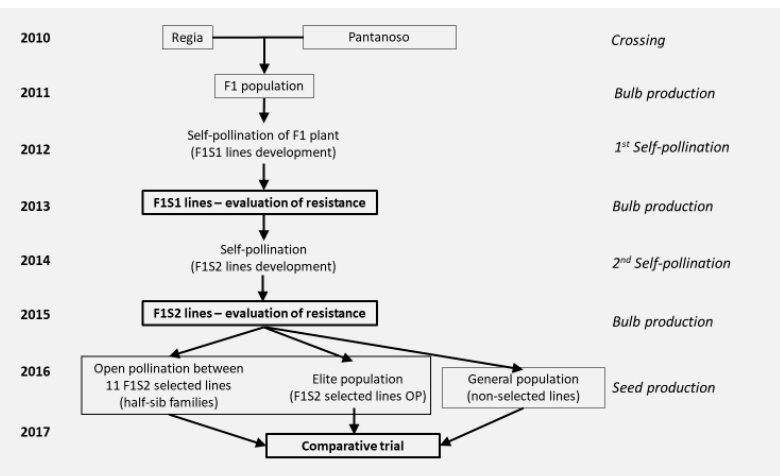

Fig 7. Breeding scheme to combine favourable agronomic traits from 'Pantanoso' with resistance against Peronospora destructor from 'Regia', resulting in the comparative trial in 2017 with eleven $F_{1} S_{2}$ advanced breeding lines and two regenerated open pollinated populations.

According to our present research, resistance against $P$. destructor could be explained by several genes, and an accumulation of favourable alleles is required for the expression of high levels of resistance.

An inheritance skewed towards susceptibility in $F_{1} S_{1}$ progenies indicate that alleles involved in resistance are recessive, in agreement with previous reports (Galván et al., 2016a; Warid and Tims, 1952). A cross with susceptible varieties prevent the phenotypical expression of these alleles, which can only be manifested in homozygosis but remain masked in heterozygous genotypes. Several examples of susceptibility genes for resistance conferring a lack of function have been reported (Pavan et al., 2010).

The cross 'Dulce' $x$ 'Regia' was the only one with skewed segregation towards resistance, and the only one in which 'Regia' was the pollen donor. This result is indicative of reciprocal effects, although such hypothesis would require further crosses and studies to be confirmed, since segregating families were composed by a few numbers of lines and cultivar 'Dulce' was not included as a control. It is necessary to confirm whether resistance from 'Regia' is influenced by cytoplasmatic genes inherited by maternal line. In this case, the expression of partial resistance from 'Regia' could be inhibited in their offspring by the interaction of nuclear alleles from the susceptible parent with cytoplasmic genes from 'Regia'. Gonzalo et al. (2007) studied reciprocal effects for several phenotypical traits in maize and identified and mapped nuclear genes involved in reciprocal effects. There is scant consensus on the relative importance and the systematic exploitation of reciprocal effects in plant breeding. Usually these effects are not consistent in all environments, nor for all genetic backgrounds (Gonzalo et al., 2007).

In this research, we only performed a phenotypic evaluation of resistance. Larger segregating families are required for a better understanding of resistance from 'Regia' integrating molecular markers to determine quantitative loci and resistance mechanisms involved. Whenever genetic effects are only additive, accumulation of favourable alleles results in greater level of resistance. For downy mildew in lettuce, a range of interactions between quantitative resistant loci have been reported, giving complexity to understanding the resistance (Den Boer et al., 2014). Identification of quantitative loci could raise information on the presence and abundance of genes involved in partial resistance from 'Regia' against $P$. destructor.

Advanced $F_{1} S_{2}$ breeding lines showed an intermediate behaviour between the parents. That was the case for the eleven lines in August, and nine of the eleven lines in November. These lines had a previous selection process (Figure 7). Nevertheless, none achieved the level of resistance in 'Regia', indicating the complex genetic base of this resistance. As well as for other complex traits like yield and adaptation, backcrosses with 'Regia' could contribute with a higher level of resistance in the progenies.

Decreasing downy mildew severity along the season (e.g., 22D, 22B and 'Naqué') could be associated to the difficult of the pathogen to reproduce and generate secondary infections. Resistance mechanisms triggered once the initial infection is installed may also involve systemic defences. As an example, the salicylic acid pathway is activated against biotrophic pathogens, like $P$. destructor, implying induction of defences in plant tissues apart from the infection site (Díaz Puentes, 2012). In contrast, line 10A presented a low initial severity but high severity at the end of the season. An effective initial resistance may indicate that plant host deploys barriers against infection, but once the pathogen is able to overcome them, development occurs with no resistance.

Disease severity evaluated in the field and the proportion of diseased stomata are different variables. Disease severity quantifies the proportion of affected leaf area, whereas the histological evaluation characterises pathogen development only within the diseased tissue. Nevertheless, we found these independent variables highly correlated. The differences in the composition of the diseased stomata may be explained by involved resistance mechanisms. A slow down in the epidemic may be due to a larger period of latency, a lower frequency of successful infections and lower rate of spore production, among others (Niks et al., 2011). We found differences among plant material in the components of partial resistance. This was due to pathogenic ability to reproduce within the host tissue through the proportion of sporulating stomata and the ability to colonize plant tissue through the proportion of stomata with infection in the substomatal chamber. For 'Regia' and high resistant breeding lines, infected leaf tissue presented a higher proportion of healthy stomata. A high proportion of health stomata can be an indirect and complementary useful variable for selection of resistance. Besides downy mildew resistance, advanced breeding lines were evaluated for agronomic variables like bulb weight and 
bulb quality. Regarding the multivariate analysis, resistance and agronomic traits can be selected independently. In comparison with national cultivars, resistant breeding lines did not differ in agronomic traits, implying that they have a similar potential for commercial purposes. The next step will be the selection of resistance combined with other interesting traits, towards the release of a new open pollinated cultivar with high performance and partial resistance against $P$. destructor, a valuable tool in an integrated disease management (Araújo et al., 2020; Ullah et al., 2020).

\section{Materials and Methods}

\section{Plant materials}

A first experiment aimed to evaluate segregating families using 'Regia' as resistance source. In 2014, 13 crosses were made to generate segregating populations. $F_{1}$ progenies resulted from individual crosses (plant to plant) between 'Regia' and national cultivars. $F_{1}$ plants were forced to flower in 2015 by an early sowing date (February) and were selfpollinated by isolation of the inflorescences with cotton bags to develop $F_{1} S_{1}$ lines and families from each cross (Figure 1). In 2015, new crosses with 'Regia' as a partial resistance source were made. $F_{1}$ plants were sown early in February 2016 for self-pollination. From each cross, a $F_{1}$ family was obtained, and subsequently from each selfed $F_{1}$ plant, a $F_{1} S_{1}$ line was acquired. A comparative trial of the $F_{1} S_{1}$ lines was installed in 2017 and presented in this paper. Fourteen segregating families were included, but in this paper only 6 of the 14 were presented, those having at least $12 F_{1} S_{1}$ lines (Figure 1).

A second experiment aimed to evaluate eleven advanced breeding lines $\mathrm{F}_{1} \mathrm{~S}_{2}$ 'Regia' x 'Pantanoso', previously selected for resistance against downy mildew. These lines came from an earlier cross (2010) between 'Regia' and 'Pantanoso' (Figure 7). F1 plants were selfed to obtain $F_{1} S_{1}$ inbred lines, and ten lines were selected for resistance. From these lines, a second self-pollination allowed development of $42 \mathrm{~F}_{1} \mathrm{~S}_{2}$ lines, evaluated in 2015. Among these S2 lines, 11 lines were selected for resistance, multiplied in open pollination in 2016, and maintained with their maternal identification (half-sib lines). The experiment to evaluate these 11 lines in 2017 is presented in this paper (Figure 7). Two advanced populations were also included: 'elite $P x R^{\prime}$, derived from the inter-pollination of the 11 lines, and a 'general PxR' derived from the F1S2 non-selected lines in 2015 (31 lines).

Four control onion cultivars were included within each replicate in the first experiment ('Casera', 'Naqué', 'Pantanoso' and 'Regia') and five in the second ('Pantanoso', 'Regia', 'Casera', 'Santina' and 'Naqué') because these cultivars showed a range of responses against the disease (Galván et al., 2016a), and were used as parents of the studied segregating populations.

\section{Experimental layout and evaluations}

The first experiment was installed at Centro Regional Sur (CRS) of the Facultad de Agronomía (Progreso, Canelones, Uruguay). Sowing was between 20 and 24 April, in seedbeds, and transplantation 16 - 22 August 2017. Harvest took place in December, regarding top fall-down of each line, and bulbs were stored under a ventilated shelter.
Experimental design was unbalanced blocks with three replications, corresponding to the available number of seeds and plots per family. The experimental plots consisted of 20 plants in four rows of five plant each row. In the periods of 7 to 10 November, downy mildew severity was evaluated as the proportion of leaf tissue affected for each plant of the plot, using a 0 to 5 ordinal scale (Table 5). Harvesting date of each plot was recorded, and agronomic traits were evaluated after harvest such as: bulb weight, diameter, neck diameter, bulb skin colour and bulb shape (according to IPGRI, 2001), and cause of losses if any (Fusarium sp., bacterial rots, sprouting, etc.). For each line, the ratio between the maximum and the neck diameters, and the frequencies of the bulb colours and shapes were calculated. Disease severity was analysed with the non-parametric test Kruskall-Wallis (Siegel, 1956). For those families with significant differences between their lines, a Tukey mean comparison was made using Infostat (Di Rienzo et al., 2018). The second experiment was installed at CRS (Progreso, Canelones, Uruguay). Sowing date was April 24 in seedling beds, and transplantation was on August 17, 2017. Downy mildew severity was evaluated two times, in August and November.

The experimental design was complete blocks with four replications. Each plot consisted of 48 plants (4 rows with 12 plants each). In order to ensure and uniformize the presence of the disease, the experiment had minimal chemical interventions, and beds with four rows of the susceptible cultivar 'Pantanoso' were inserted between experimental plots.

Disease severity was evaluated on the ten central plants of the plot, using an ordinal scale from 0 to 5 (Table 1). In the second evaluation, the cultivars 'Casera' and 'Regia' were already fall with senescent foliage; thus were not evaluatednor included in the analysis for November. Data were analysed with the Kruskall-Wallis test (Siegel, 1956) and a Tukey comparison of means. Agronomic traits and bulb quality were evaluated after harvest.

Quantitative agronomic traits were subjected to ANOVA, and those having significant differences between means with a Tukey comparison using Infostat (Di Rienzo et al., 2018).

\section{Histological evaluations}

Simultaneously, to evaluate the disease severity in August and November, four samples of affected leaf tissue with visible sporulation were taken from each experimental plot for a quantitative histological analysis. Leaf pieces $2 \times 2 \mathrm{~cm}$ were cut off on the laboratory bench and cleared during 48 hours in alcohol $95 \%$, changing the alcohol at 24 hours, and afterwards preserved in alcohol 95\%. Staining for microscopic quantitative evaluations comprised of immersion for $5 \mathrm{~min}$ in $0.01 \%$ Calcofluor White (Kortekamp, 2005; Arias et al., 2015) followed by observations under microscope (Figure 2). For each sample, 100 stomata were observed and assigned to a proportion of the following classes: health $(\mathrm{H})$, sporulating $(\mathrm{S})$ or stomata with visible infection in the underneath stomatal chamber (I). The proportions were transformed by quadratic function and analysed by ANOVA and Tukey's tests in Infostat (Di Rienzo et al., 2018).

A multivariate analysis (PCA) was performed using PAST (Hammer et al., 2001). Data matrix comprised downy mildew severity in August and November, the proportion of 
healthy stomata in the histological analysis in both evaluation times, and agronomic traits (bulb weight, postharvest conservation five months after harvest, percentage of bolting).

\section{Conclusions}

Inheritance of partial resistance from 'Regia' was confirmed in segregating populations, as well as the occurrence of reciprocal effects. However, determination of the genetic basis of resistance will require more studies involving larger segregating populations and molecular markers. Advanced breeding lines did not reach the level of resistance in 'Regia'. Nevertheless, highly downy mildew resistant advanced breeding lines carried favourable agronomic traits and allowed the development of a competitive open pollinated downy mildew resistant cultivar in comparison to currently available cultivars.

\section{Acknowledgements}

The first author acknowledges the postgraduate fellowship from Sistema Nacional de Becas, Agencia Nacional de Investigación e Innovación (SNB-ANII), Uruguay.

\section{References}

Aghnoum R, Niks RE (2011) Transgressive segregation for very low and high levels of basal resistance to powdery mildew in barley. J Plant Physiol. 168: 45-50.

Alves DP, de Araújo ER, Wamser GH, de Souza Gonçalves PA, Marinho, CD, Tomaz RS (2018) Field performance and screening for resistance to Peronospora destructor of 46 onion cultivars in Brazil. Australas. Plant Dis. Notes 13 (1): 5.

Araújo ER, Resende RS, Alves DP, Higashikawa FS (2020a) Integrating cultivar resistance and disease warning system to control downy mildew of onion. Australas. Plant Dis. Notes 15(1): 1.

Araújo ER, Resende RS, Alves DP, Higashikawa FS (2020b) Field efficacy of fungicides to control downy mildew of onion. Eur. J. Plant Path. 156: 305-309.

Arias M, González PH, Galván GA (2015) Análisis histológico del proceso de infección de Peronospora destructor, causante del mildiú de la cebolla. Summary presented in: 3rd Jornada Nacional de Fitopatología, Montevideo, Uruguay, 3 de setiembre de 2015.

Colnago P, González PH, Noguez M, Bentancur O, Galván GA (2012) Evaluación de la respuesta a Peronospora destructor (Berk.) Casp. en el germoplasma local de cebolla. Agrociencia Uruguay 16(1): 33-44.

Den Boer E, Pelgrom KTB, Zhang NW, Visser RGF, Niks RE, Jeuken MJW (2014) Effects of stacked quantitative resistances to downy mildew in lettuce do not simply add up. Theor. Appl. Gen. 127: 1805-16.

Díaz-Puentes LN (2012) Resistencia sistémica adquirida mediada por el ácido salicílico. Biotecn. en el Sector Agropec. Agroind. 10:257-267.

Di Rienzo JA, Casanoves F, Balzarini MG, Gonzalez L, Tablada M, Robledo CW (2018) InfoStat versión 2018. Centro de Transferencia InfoStat, Facultad de Ciencias Agropecuarias, Universidad Nacional de Córdoba, Argentina. URL http://www.infostat.com.ar

Galván GA, Arias M, González PH, Curbelo N, Peluffo S (2016a) Selection for resistance and histopathological relationships in the onion 'Regia' against downy mildew (Peronospora destructor). Acta Hort. 1143:15-22.

Galván GA, Vicente E, Arias M, González Rabelino P (2016b) Selección por resistencia a Peronospora destructor en el mejoramiento genético de cebolla (Allium cepa L.). 16th Congreso Latinoamericano de genética, Montevideo, Uruguay. J. Basic Appl. Gen. 27 (1)S:295.

González PH, Colnago P, Peluffo S, González Idiarte H, Zipitria J, Galván GA (2011) Quantitative studies on downy mildew (Peronospora destructor Berk. Casp.) affecting onion seed production in southern Uruguay. Eur. J. Plant Path. 129: 303-314.

Gonzalo M, Vyn T, Holland JB, Mcintyre LM (2007) Mapping reciprocal effects interactions with density stress in Zea mays L. Heredity 99: 14-30.

Hammer $\varnothing$, Harper DAT, Ryan PD (2001) PAST: paleontological statistics software package for education and data analysis. Paleontol. Electron 4: 9.

IPGRI, ECP/GR, AVRDC (2001) Descriptors for Allium (Allium spp.). International Plant Genetic Resources Institute, Rome, Italy; European Cooperative Programme for Crop Genetic Resources Networks (ECP/GR), Asian Vegetable Research and Development Center, Taiwan. 51p.

Jones HA, Porter DR, Leach LD (1939) Breeding for resistance to onion downy mildew caused by Peronospora destructor. Hilgardia 12: 531-550.

Kofoet A, Zinkernagel V (1989) Resistance to downy mildew (Peronospora destructor (Berk.) Casp.) in Allium species. J. Plant. Dis. Protec. 97: 13 -23.

Kortekamp A (2005) Growth, occurrence and development of septa in Plasmopara viticola and other members of the Peronosporaceae using light- and epifluorescencemicroscopy. Mycol. Res. 109:640-648.

Lorbeer JW, Kuhar TP, Hoffmann MP (2002) Monitoring and forecasting for disease and insect attack in onions and Allium crops within IPM strategies. In H.D. Rabinowitch, L. Currah (Ed.), Allium crop science: recent advances. CABI Publishing. pp. 293-310.

Maeso D, Arboleya J, Fernández S, Suárez C, Medina V (2000) Evaluación de un sistema de pronóstico para el control de enfermedades foliares en diferentes cultivares de cebolla. En: Presentación de resultados experimentales en ajo y cebolla: Reunión de divulgación. Montevideo: INIA Serie Actividades de difusión, 223. pp. 17-29.

McMullen MD, Kresovich S, Villeda HS, Bradbury P, Li H, Sun Q, Flint-Garcia S, Thornsberry J, Acharya C, Bottoms C et al (2009) Genetic properties of the maize nested association mapping population. Science 325 (5941):737-740.

Niks RE, Parlevliet JE, Lindhout P, Bai Y (2011) Breeding crops with resistance to diseases and pests. Enfield : Enfield Pub \& Distribution Co. 200p.

Pavan S, Jacobsen E, Visser RGF, Bai Y (2010) Loss of susceptibility as a novel breeding strategy for durable and broad-spectrum resistance. Mol. Breed. 25:1-12.

Scholten OE, Van Heusden AW, Khrustaleva LI, BurgerMeijer K, Mank RA, Antonise RGC, Harrewijn JL, Van Haecke W, Oost EH, Peters RJ, Kik C (2007) The long and winding road leading to the successful introgression of downy mildew resistance into onion. Euphytica 156: 345353.

Schwartz HF, Mohan SK (2008) Compendium of onion and garlic diseases. St Paul: APS Press. 54p.

Siegel S (1956) Non-parametric statistics for the behavioral sciences. McGraw-Hill Book Co. 312 pp. 
Ullah S, Atiq M, Younas M, Rajput NA, Sahi ST, Sharif A, Talib MZ, Fatima K, Majeed MU, Ashraf W, Raza H (2020)

Monitoring of epidemiological factors promotive for the expansion of downy mildew of onion and its chemotherapeutic management under field conditions. Intern J. Biosc. 16: 173-182.

Warid W, Tims EC (1952) Studies on the inheritance of resistance to downy mildew studies in onion incited by Peronospora destructor. Phytopathology 42: 22. 